\title{
Effectiveness of Tonic and Burst Motor Cortex Stimulation in Chronic Neuropathic Pain [Corrigendum]
}

\author{
Sokal P, Harat M, Malukiewicz A, Kiec M, Świtońska M, \\ Jabłońska R. J Pain Res. 2019;12:1863-1869.
}

On page 1868, Reference 32, "Ivanishvili Z, Poologaindran A, Honey CR. Cyclization of motor cortex stimulation for parameters for motor cortex stimulation. Neuromodulation. 2015;18(7):566-571" should have been "Ivanishvili Z, Poologaindran A, Honey CR. Cyclization of Motor Cortex Stimulation for Neuropathic Pain: A Prospective,
Randomized, Blinded Trial. Neuromodulation: Technology at the Neural Interface. 2017;20(5):497-503. doi:10.1111/ ner.12610".

Following feedback from a reader, we found the incorrect details were presented for reference 32 . The authors apologize for this error.

\section{Publish your work in this journal}

The Journal of Pain Research is an international, peer reviewed, open access, online journal that welcomes laboratory and clinical findings in the fields of pain research and the prevention and management of pain. Original research, reviews, symposium reports, hypothesis formation and commentaries are all considered for publication. The manuscript management system is completely online and includes a very quick and fair peer-review system, which is all easy to use. Visit http:// www.dovepress.com/testimonials.php to read real quotes from published authors. 